\title{
Single and double doses of doxycycline for the treatment of gonorrhoea
}

\author{
L. Z. OLLER, J. C. EDWARDS, AND KATHLEEN M. LUMB \\ St. Luke's Hospital, Bradford, Yorkshire
}

Doxycycline monohydrate (Vibramycin), a synthetic derivative of oxytetracycline, shows some important properties which are not shared by any other tetracycline analogue. It is rapidly and almost completely absorbed, its absorption is virtually unaffected by food, it has a prolonged serum half-life, and it is highly lipo-soluble resulting in high tissue levels. Taking into consideration the known anti-gonococcal activity of tetracycline derivatives, these properties are likely to make single doses of doxycycline adequate for the treatment of gonorrhoea.

Most published reports bear out this assumption. Single doses of $200 \mathrm{mg}$ doxycycline which were used for the treatment of gonorrhoea in men by Lassus (1968) in Finland and by van Steenbergen (1971) in the Netherlands resulted in cure rates of 86 and 88 per cent. respectively. Single doses of 250 mg. used by Domescik, McLone, Scotti, and Mackey (1969) in the U.S.A. cured 95.3 per cent. of cases of gonorrhoea in men. Single doses of $300 \mathrm{mg}$. have been used by several investigators with variable results. The failure rate ranged from 12.7 per cent. reported in London by Gray, Phillips, and Nicol (1970) to 2.4 per cent. reported in Sweden by Lidén, Hammar, Hillström, Wallin, and Öhman (1971). Other authors using this dosage include Sylvestre and Gallai (1968) in Canada, Lassus (1968) in Finland, and more recently Masterton and Schofield (1972) and Moffett, McGill, Masterton, and Schofield (1972) in Glasgow; these authors recorded failure rates of $5,6,6 \cdot 4$, and 5.8 per cent. respectively. Bartunek (1971) in Germany treated 100 women suffering from gonorrhoea with $600 \mathrm{mg}$. divided into two equal doses taken at an interval of 24 hours and attained a 93 per cent. cure rate; the seven patients who relapsed were re-treated with the same dosage of doxycycline, the interval being shortened to 12 hours, and all seven were then cured.

Received for publication September 1, 1972

\section{Material and Methods}

In the present trial, 145 patients with uncomplicated gonorrhoea, 100 men and 45 women, were treated with $400 \mathrm{mg}$. doxycycline. The first fifty, all men, were given the whole dose ( 4 capsules) at once in the clinic; the remaining 95 patients were given $200 \mathrm{mg}$. in the clinic and instructed to take the other two capsules at home 1 to 2 hours later, after a meal.

Of the male patients, fifty were white ( 38 born in the United Kingdom) and fifty coloured ( 32 from the subcontinent of India). The ages ranged from 17 to 70 years (average 30.4). With the exception of two West Indians, all the women were white with an age range from 16 to 47 years (average 26.1). Pregnant women, patients who could not be followed up (temporary residents, long distance lorry drivers, etc.), and known prostitutes were excluded from entry into the trial.

Treatment was given on the strength of a positive Gram-stained smear. Cultures (heated blood agar) were incubated in the clinic overnight and then submitted to the Public Health Laboratory for identification and sensitivity tests. Sensitivity of gonococci to penicillin was tested with impregnated filter-paper discs of four concentrations from 0.062 to 0.5 unit. Sensitivity to streptomycin and tetracycline was tested by dried discs, each of 10 $\mu \mathrm{g}$. potency. In addition impregnated discs containing $0 \cdot 25,0.5,1,2$, and $4 \mu \mathrm{g}$. doxycycline were prepared in batches of 100; these discs were used to test the isolates from ninety patients.

Criteria for cure in men were absence of urethral discharge, clear urine, and negative smear and culture from prostatic fluid expressed after 14 days.

Criteria for cure in women were negative smears and cultures from three post-treatment examinations, including one after the menses. In the case of couples, if one partner was adequately followed up after resumption of sexual intercourse, the other partner was presumed to be cured.

Fifteen men and seven women were assessed in this way. Altogether there were 61 couples; in twenty of them both partners, in 22 only the male partners, and in nineteen only the female partners were treated with doxycycline. 


\section{Results}

\section{SENSITIVITY TESTS}

In two male cases the gonococcus was not isolated. The results of the sensitivity tests in the remaining 143 are shows in Table $I$.

There were 49 isolates ( 34 per cent.) with a diminished sensitivity to penicillin and 45 ( 31 per cent.) resistant to streptomycin. Diminished sensitivity to penicillin was mostly associated with resistance to streptomycin, and the association was 100 per cent. in isolates not inhibited by 0.25 and $0.5 \mathrm{u}$. penicillin.

Of the ninety isolates tested for disc-sensitivity to doxycycline, two were inhibited by $0.25 \mu \mathrm{g}$., seventeen by $0.5 \mu \mathrm{g}$., 43 by $1 \mu \mathrm{g} ., 23$ by $2 \mu \mathrm{g}$., and four by $4 \mu \mathrm{g}$. The one isolate which was not inhibited by $4 \mu \mathrm{g}$. was also resistant to $10 \mu \mathrm{g}$. tetracycline. A comparison of these results with the sensitivities of the same isolates to penicillin and streptomycin is shown in Table II.
Isolates less sensitive to penicillin and resistant to streptomycin generally showed a lesser degree of sensitivity to doxycycline. In the largest group of 43 isolates which were inhibited by $1 \mu \mathrm{g}$. doxycycline, there were eight (18.6 per cent.) relatively resistant to penicillin and eleven ( 25.5 per cent.) resistant to streptomycin. Of the nineteen which were inhibited by less than $1 \mu \mathrm{g}$. there were only two (10.5 per cent.) less sensitive to penicillin and three $(15.8$ per cent.) resistant to streptomycin, whereas among the 28 which required $2 \mu \mathrm{g}$. or more doxycycline for inhibition there were fourteen (50 per cent.) less sensitive to penicillin and sixteen (57 per cent.) resistant to streptomycin.

\section{CLINICAL RESULTS (Table III)}

In the group of fifty men treated by a single dose, 44 could be assessed, and 42 of them were cured; one who vomited 10 minutes after treatment was not cured and one attended with a fresh infection

TABLE I Sensitivities of 143 isolates of N. gonorrhoeae to penicillin, streptomycin, and tetracycline

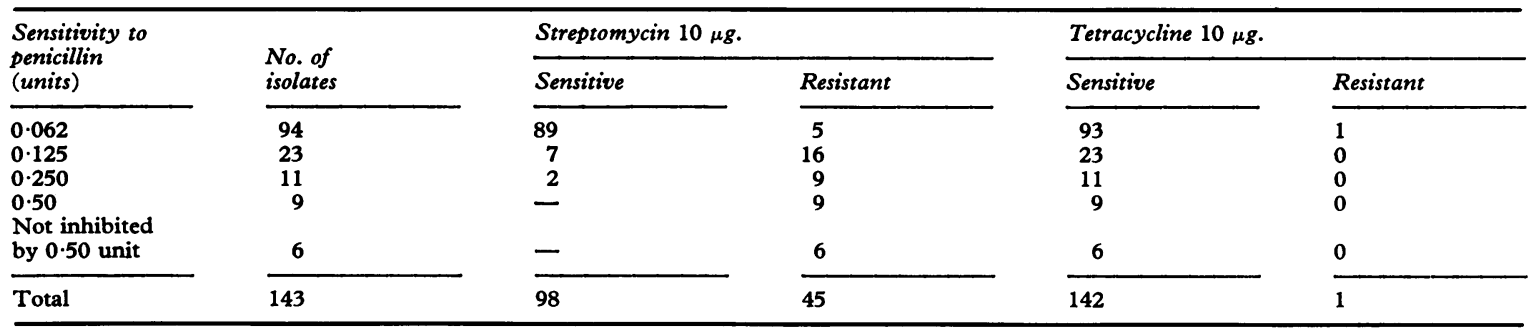

TABLE II Sensitivities to doxycycline of ninety isolates of $\mathrm{N}$. gonorrhoeae compared with sensitivities to penicillin and streptomycin

\begin{tabular}{|c|c|c|c|c|c|c|c|c|}
\hline \multirow{2}{*}{$\begin{array}{l}\text { Sensitive to } \\
\text { doxycycline } \\
(\mu g .)\end{array}$} & \multirow{2}{*}{$\begin{array}{l}\text { No. of } \\
\text { isolates }\end{array}$} & \multicolumn{5}{|c|}{ Sensitive to penicillin (units) } & \multicolumn{2}{|c|}{ Streptomycin $10 \mu \mathrm{g}$} \\
\hline & & 0.0625 & $0 \cdot 125$ & $0 \cdot 25$ & 0.5 & $>0.5$ & Sensitive & Resistant \\
\hline $\begin{array}{l}0 \cdot 25 \\
0 \cdot 50 \\
1 \cdot 00 \\
2 \cdot 00 \\
4 \cdot 00 \\
>4 \cdot 00\end{array}$ & $\begin{array}{r}2 \\
17 \\
43 \\
23 \\
4 \\
1\end{array}$ & $\begin{array}{r}2 \\
15 \\
35 \\
12 \\
2 \\
0\end{array}$ & $\begin{array}{l}0 \\
2 \\
3 \\
1 \\
0 \\
0\end{array}$ & $\begin{array}{l}0 \\
0 \\
4 \\
4 \\
0 \\
1\end{array}$ & $\begin{array}{l}0 \\
0 \\
0 \\
3 \\
2 \\
0\end{array}$ & $\begin{array}{l}0 \\
0 \\
1 \\
3 \\
0 \\
0\end{array}$ & $\begin{array}{r}1 \\
15 \\
32 \\
10 \\
2 \\
0\end{array}$ & $\begin{array}{r}1 \\
2 \\
11 \\
13 \\
2 \\
1\end{array}$ \\
\hline Total & 90 & 66 & 6 & 9 & 5 & 4 & 60 & 30 \\
\hline
\end{tabular}

TABLE II I Results of treatment with doxycycline

\begin{tabular}{|c|c|c|c|c|c|}
\hline Dosage & No. treated & Assessed & Cured & Relapsed & Re-infected \\
\hline $400 \mathrm{mg}$. stat & 50 men & 44 & 42 & 1 & 1 \\
\hline $200 \mathrm{mg} . \times 2$ & $\begin{array}{l}50 \text { men } \\
45 \text { women }\end{array}$ & $\begin{array}{l}46 \\
42\end{array}$ & $\begin{array}{l}45 \\
39\end{array}$ & $\overline{2}$ & $\begin{array}{l}1 \\
1\end{array}$ \\
\hline Total & 145 & 132 & 126 & 3 & 3 \\
\hline
\end{tabular}


after 14 days. In the group of 95 patients treated by double doses, 46 men and 42 women were assessed; 45 men and 39 women were cured, two women relapsed, and one man and one woman were reinfected. All three re-infections were verified by epidemiological investigations. One of the women who relapsed was found to be a prostitute and should not have been included in the trial; she was probably re-infected.

Three men needed additional treatment for nonspecific urethral infection which had been acquired, as far as could be ascertained, concomitantly with the gonorrhoea.

\section{SIDE-EFFECTS}

In the group of fifty men who were given $400 \mathrm{mg}$. as a single dose, twelve vomited. Three did so within $30 \mathrm{~min}$. (including the one who vomited after 10 min.), eight between 30 and $60 \mathrm{~min}$., and one after $4 \mathrm{hrs}$. Thirteen complained of nausea. In all these cases the dose had been taken on an empty stomach, whereas, in those who had recently eaten, tolerance was good. Of the fifty men and 45 women who took doxycycline in divided doses, one man and two women vomited within an hour of the first dose. Four men and four women complained of nausea. The second dose, which was given $1 \frac{1}{2}$ to 2 hours later, was well tolerated in all cases.

\section{Discussion}

There are two aspects of this trial to consider:

(1) There is a frequent correlation of diminished sensitivity to doxycycline with that to penicillin in vitro. In the present trial this appears to be of only theoretical interest, as even the patient who was infected with a strain of gonococcus which was not inhibited in vitro by $4 \mu \mathrm{g}$ doxycycline responded well to $400 \mathrm{mg}$. of the drug. Moreover, there were four patients in our series (three men and one woman), who were infected with gonococci shown in vitro to have lessened sensitivity to penicillin, and who had failed to respond to penicillin but were cured with doxycycline. On the other hand, Lassus (1970) noted that the effectiveness of doxycycline was reduced in such cases. Seven (17 per cent.) of the 41 patients whom he had treated unsuccessfully with penicillin did not respond to re-treatment with $300 \mathrm{mg}$. doxycycline. This contrasts with the 6 per cent. failure rate he had reported 2 years previously (Lassus, 1968), using the same dosage of doxycycline.

(2) There is a high incidence of side-effects after large doses of doxycycline. Although these are not serious, do not alarm the forewarned patient, and occur mostly after the drug is taken on an empty stomach, they may influence the outcome if the patient vomits before the drug has had time to be absorbed. This happened to one of our patients who vomited 10 minutes after taking $400 \mathrm{mg}$. doxycycline, and premature vomiting was the presumed cause of four out of twelve failures reported from Glasgow in the two papers previously mentioned. In Glasgow the problem was overcome by giving the $300 \mathrm{mg}$. doxycycline with a drink of milk. We greatly reduced the incidence of vomiting by dividing the treatment into two $200 \mathrm{mg}$. doses, the second dose being taken after a meal. Before resorting to double doses, we carried out an evaluation on five men who were given $15 \mathrm{ml}$. magnesium trisilicate mixture before a single dose of $400 \mathrm{mg}$. doxycycline. There were no side-effects, but in all five gonococci persisted in the urethral discharge. Antacid preparations should therefore not be given if treatment with doxycycline or any other tetracycline is contemplated.

\section{Summary and Conclusions}

145 patients with uncomplicated gonorrhoea were treated with $400 \mathrm{mg}$. doxycycline (Vibramycin). The first fifty, all men, were given the whole dose at once; of the 44 assessed, one patient was not cured (2.3 per cent. failure rate). The remaining fifty men and 45 women received two doses of 200 mg., the second dose being taken $1 \frac{1}{2}$ to 2 hours after the first and after a meal. Of these patients, 88 were assessed and two women relapsed $(2 \cdot 3$ per cent. failure rate), one of whom was probably re-infected.

Disc-sensitivity tests, using five strengths of doxycycline, were carried out on isolates of $N$. gonorrhoeae from ninety patients. Analysis of the results showed that the isolates which were less sensitive to penicillin and resistant to streptomycin were mostly also less sensitive to doxycycline. This did not affect the results.

Side-effects (nausea and vomiting) were frequent in patients who took the $400 \mathrm{mg}$. doxycycline in one dose on an empty stomach, and vomiting after 10 minutes was most probably responsible for the one failure of treatment in this group.

Doxycycline $400 \mathrm{mg}$., divided into two equal doses, the second dose being taken after the next meal, is a highly effective and acceptable form of treatment for gonorrhoea in men and women.

We wish to thank Dr. H. G. Smith, Director of Bradford Public Health Laboratory, and his staff for the laboratory work, and Mr. N. Allen of Pfizer Limited for the supply of Vibramycin used in this trial and for his practical help. 


\section{References}

BARTUNEK, J., (1971) Med. Welt (Stuttgart), 22, 564

DOMESCIK, G., MCLONE, D. G., SCOTTI, A., and MACKEY, D. M. (1969) Publ. Hlth Rep. (Wash.), 84, 182

Gray, R. C. F., Philips, I., and Nicol, C. S. (1970) Brit. F. vener. Dis., 46, 401

LAssus, A. (1968) Chemotherapy (Basel), 13, 366 (1970) Ibid., 15, 125

Lidén, S., Hammar, H., Hillström, L., Wallin, J., and Öhman, S. (1971) Acta derm.-venereol. (Stockh.), 51,221

Masterton, G. and Schofield, C. B. S. (1972) Brit. F. vener. Dis., 48, 121

Moffett, M., McGill, M. I., Masterton, G., and SCHOFIELD, C. B. S. (1972) Ibid., 48, 126

Sylvestre, L., and Gallai, Z. (1968) Un. méd. Canad., 97, 639

VAN STEENBERgen, E. P. (1971) Brit. F. vener. Dis., 47, 111

La doxycycline à dose unique et à dose double dans le traitement de la gonococcie

\section{SOMMAIRE}

145 malades atteints de gonococcie non compliquée furent traités par $400 \mathrm{mg}$ de doxycycline (Vibramycine). Les 50 premiers, tous hommes, reçurent toute la dose d'emblée; parmi les 44 retenus, un malade ne fut pas guéri (2,3 pour cent d'échec). Les 50 hommes restant et 45 femmes reçurent deux doses de $200 \mathrm{mg}$, la deuxième dose étant prise $1 \frac{1}{2}$ à 2 heures après la première et après un repas. 88 de ces malades furent retenus: 2 femmes rechutèrent (2,3 pour cent d'échec) dont l'une fut probablement réinfectée.

Sur 90 malades, on étudia la sensibilité du $N$. gonorrhoeae, par la technique des disques, à 5 dilutions de doxycycline. L'analyse des résultats montra que les échantillons qui étaient moins sensibles à la pénicilline et résistants à la streptomycine furent, pour la plupart, moins sensibles à la doxycycline. Ceci n'influença pas les résultats.

Les effets secondaires (nausée et vomissement) furent fréquents chez les malades recevant $\mathbf{4 0 0} \mathbf{m g}$ de doxycycline en une seule dose, l'estomac vide; le vomissement dans les 10 minutes fut probablement responsable du seul échec dans ce groupe.

Une dose de $\mathbf{4 0 0} \mathrm{mg}$ de doxycycline donnée en deux doses égales-la deuxième après le repas suivant-est très efficace et représente une modalité convenable du traitement de la gonococcie chez l'homme et chez la femme. 